
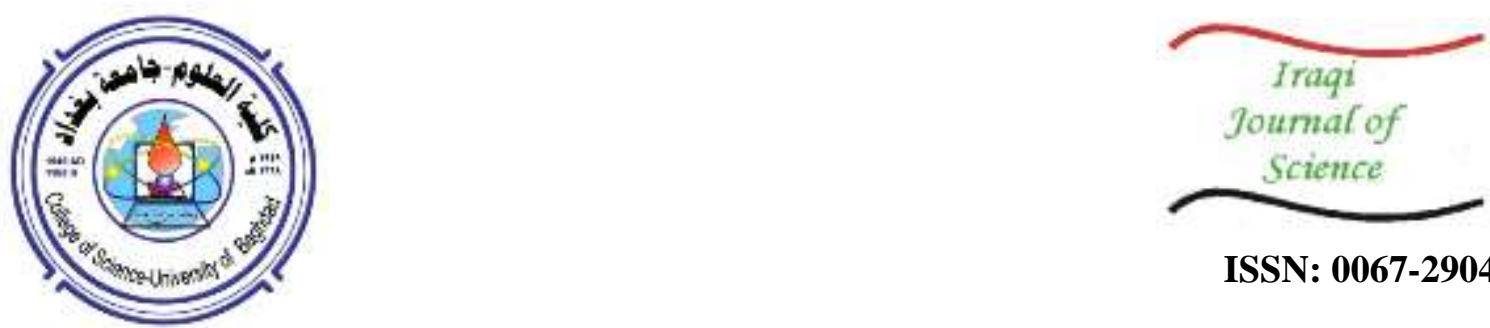

ISSN: 0067-2904

\title{
Extraction and Characterization of Chitosan from Crab Shells: Kinetic and Thermodynamic Studies of Arsenic and Copper Adsorption from Electroplating Wastewater
}

\author{
Sumaila A. ${ }^{* 1,3}$, Ndamitso M. M. ${ }^{1}$, Iyaka Y.A. ${ }^{1}$, Abdulkareem, A.S. ${ }^{2}$, Tijani J. O. ${ }^{1}$, Idris \\ M.O. ${ }^{3}$ \\ ${ }^{1}$ Department of Chemistry, Federal University of Technology Minna, Niger State \\ ${ }^{2}$ Department of Chemical Engineering, Federal University of Technology Minna, Niger State \\ ${ }^{3}$ Department of Pure and Industrial Chemistry, Prince Abubakar Audu University Anyigba, Kogi State
}

\begin{tabular}{ll}
\hline Received: 14/7/2019 Accepted: $17 / 12 / 9019$
\end{tabular}

\begin{abstract}
Crab shells were used to produce chitosan via the three stages of deproteinization, demineralization and deacetylation using sodium hydroxide and hydrochloric acid under different treatment conditions of temperature and time. The produced chitosan was characterized using Fourier transform infrared spectroscopy (FTIRS), X-ray diffraction (XRD), high - resolution scanning electron microscopy (HRSEM), electron dispersion spectroscopy (EDS), dynamic light scattering (DLS), Brunauer Emmett Teller (BET) and Thermogravimetric analysis (TGA). The adsorption behavior of chitosan to remove arsenic (As) and copper $(\mathrm{Cu})$ from electroplating wastewater was examined by batch adsorption process as a function of adsorbent dose, contact time and temperature. The FTIR, XRD, HRSEM and EDS analyses confirmed, respectively, the presence of $-\mathrm{NH}_{2}$ and $-\mathrm{OH}$ functional groups, with amorphous/crystalline phases, crystallinity index of $69.54 \%$, needlelike morphology and Carbon $(\mathrm{C})$, Oxygen $(\mathrm{O})$ and Nitrogen $\mathrm{N}$ ) in the produced chitosan. While DLS, BET and TGA showed, respectively, that the produced chitosan has an average particle size of $729 \mathrm{~nm}$, is moderately polydisperse, has 12.67 $\mathrm{m}^{2} / \mathrm{g}$ surface area, mesoporous in nature, and with thermal stability of up to $143^{\circ} \mathrm{C}$. The optimum adsorbent dose, contact time and temperature values to remove As and $\mathrm{Cu}$ by chitosan were $15 \mathrm{mg}, 45$ minutes, $333 \mathrm{~K}$ and $25 \mathrm{mg}, 60$ minutes, $349 \mathrm{~K}$, respectively. Under the employed conditions, chitosan though has a low surface area, displaying high adsorption capacity for both metal ions. The adsorption isotherm data were better fitted to the Jovanovic isotherm model while the kinetic data fitted best to the pseudo-second order model. The thermodynamic studies established that the adsorption was feasible but endothermic in nature. This study shows that chitosan adsorbents purify electroplating wastewater.
\end{abstract}

Keywords: Chitosan, adsorption, arsenic, copper, electroplating wastewater.

\section{INTRODUCTION}

The global rapid increase in anthropogenic and industrial activities such as mining, metal ores processing, tanning, electroplating, petrochemical processing, among others, have led to an enormous increase in the generation and release of toxic wastes into the environment [1]. Among the toxic wastes discharged into the environment are heavy metals-containing wastes which have been a significant threat to life due to their non-biodegradability, mobility and bio-accumulation in the environment [2]. Heavy metals such as mercury, lead, zinc, arsenic, among others, are potentially toxic to the environment, especially to humans and aquatic lives, and their impacts keep on increasing

*Email: muminislam2012@gmail.com 
daily [3].These toxic metals from the environment become accumulated into the living tissues of humans through the food chain, of which man receives the maximum impact, being the top of the chain [4]. The adverse health effects of these toxic metals in humans range from abdominal disorders to cancer, while sometimes causing death [5]. Hence, heavy metal contamination, being a critical problem constituted by wastewater generated by industries, needs to be sequestrated before discharge into the environment.

Adequate sequestration of toxic heavy metals from industrial wastewater is a serious environmental concern and has been continuously studied [6]. Different treatment methods frequently employed previously to sequestrate heavy metals from wastewater include oxidation [7], chemical precipitation [8], electrochemical treatment [9], ion exchange [10], membrane process [11] and ultrafiltration [12]. Despite the adequate results achieved using these methods, there are some limitations such as high operational cost, use of heavy chemicals, generation of secondary wastes and low adsorption efficiency. In view of these limitations, alternative, more effective and low-cost methods are desired, among which the adsorption technology has been shown to have a very large extent. Consideration of adsorption technology as an alternative technique is due to its flexibility, costeffectiveness and high efficiency for the removal of heavy metals from wastewater that contains heterogeneous pollutants [13].

Several adsorbents which have been used for the removal of heavy metal ions from wastewater include activated carbon [14], porous clay [15], zeolite [16] and bagasse fly ash [17, 18]. However, these adsorbents exhibit low adsorption efficiency, absence of adequate number of active sites and generation of secondary wastes. Therefore, there is a need to produce ecofriendly and low-cost adsorbents of high adsorption efficiency for the treatment of industrial wastewater.

Chitosan is a biopolymer which can be extracted from crab shells. The structure of chitosan is presented schematically in Figure-1. The high number of amino and hydroxyl groups of this natural polymer results in unique binding properties for heavy metal ions such as arsenic, copper, iron, lead and zinc[19]. For about three decades, chitosan has been used globally for water purification processes. Some of the features that made chitosan commercially attractive as biopolymer include its natural abundance, non-toxic nature and bio-decomposition in the environment with no side effects [20].

In this study, production and characterization of chitosan via deproteinization, demineralization and deacetylation using sodium hydroxide and hydrochloric acid were carried out. In addition, the efficiency of the produced chitosan for adsorption of arsenic and copper from electroplating wastewater was investigated. The effects of contact time, adsorbent dose and temperature were studied to understand the adsorption mechanism of selected heavy metals removal from the electroplating wastewater by the produced chitosan.

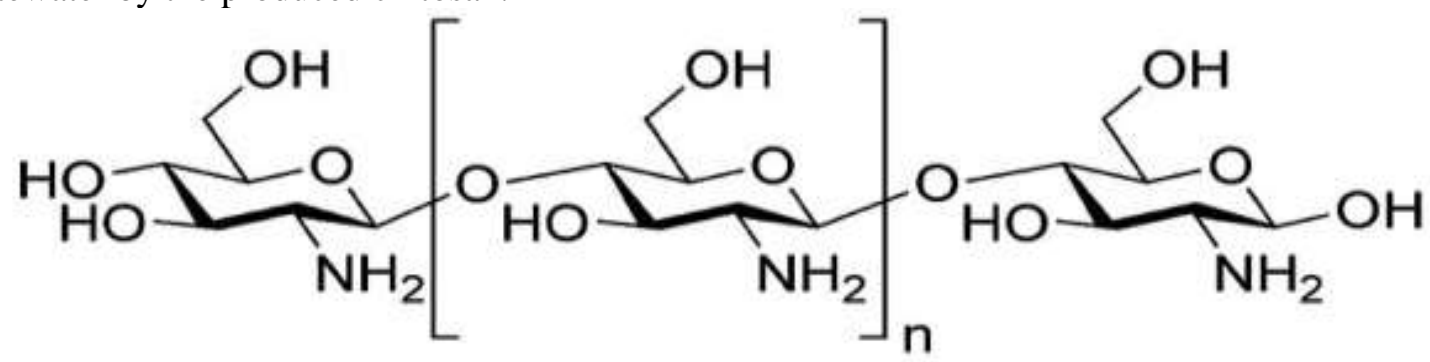

Figure 1- Chemical structure of chitosan

\section{MATERIALS AND METHODS}

Materials and Samples Preparation: Crab shells used in this study were obtained from a local fish market at New Bussau, Niger State, Nigeria. Electroplating wastewater was collected from the discharge point of the electroplating section of SEDI Minna, Niger State, Nigeria. The chemicals used in this study include sodium hydroxide, hydrochloric acid and nitric acid, all supplied by BDH Chemicals England. All the chemicals were of analytical grade with percentage purity in the range $96.60-99.90 \%$ and were used without further purification.

The crab shells were thoroughly washed to remove sand, dirt and other impurities using distilled water. The washed shells were air-dried for two weeks and pulverized using mortar and pestle. The 
particles were sieved to fine sizes using a sieve of $2.0 \mathrm{~mm}$ mesh size to ensure uniform particle sizes for easy extraction. The sieved shell sample was stored in an opaque glass bottle for further analysis.

\section{Methods}

Extraction of Chitosan from Crab Shells: The production of chitosan from the powdered crab shells was carried out via three main stages of extraction: deproteinization, demineralization and deacetylation.

Deproteinization of the Crab Shells: The crab shells were deproteinized by treating $5 \mathrm{~g}$ of the crab shells in $250 \mathrm{~cm}^{3}$ beaker using $1.25 \mathrm{M} \mathrm{NaOH}$ for $3 \mathrm{hrs}$ at room temperature, after which the mixtures were allowed to settle. Excess $\mathrm{NaOH}$ was removed by decantation, followed by washing with deionized water to neutral $\mathrm{pH}$. Filtration was performed using Whatman filter paper No 4 . The residue was oven-dried at $80{ }^{\circ} \mathrm{C}$ for 45 minutes to obtain a deproteinized material.

Demineralization of Deproteinized Crab Shells: In the step of demineralization of the deproteinized crab shells, $3 \mathrm{~g}$ of the deproteinized material was treated in $250 \mathrm{~cm}^{3}$ conical flask using $1.25 \mathrm{M}$ of $\mathrm{HCl}$ for $5 \mathrm{hrs}$ at $80^{\circ} \mathrm{C}$. After heating, the mixture was allowed to cool and settle. Excess $\mathrm{HCl}$ was removed by decantation, followed by washing with deionized water to neutral $\mathrm{pH}$. This was subsequently followed by filtration using Whatmann filter paper No 4 and the residue obtained was oven-dried at $80^{\circ} \mathrm{C}$ for 45 minutes to obtain chitin.

Deacetylation of Chitin: To carry out the deacetylation of the obtained chitin to produce chitosan, $1 \mathrm{~g}$ of the chitin in $100 \mathrm{~cm}^{3}$ beakers was treated using $0.5 \mathrm{M}$ of $\mathrm{NaOH}$ for $2 \mathrm{hrs}$ at $100^{\circ} \mathrm{C}$. After heating, the mixture was allowed to cool and settle. Excess $\mathrm{NaOH}$ was removed by decantation, followed by washing with deionized water to neutral $\mathrm{pH}$. Thereafter, filtration was performed using Whatman filter paper No 4, the residue was oven-dried at $80{ }^{\circ} \mathrm{C}$ for 45 minutes and chitosan was obtained.

Determination of Physicochemical Parameters of the Extracted Chitosan

Moisture Content of the Extracted Chitosan: The moisture content determination of the extracted chitosan was carried out as follows: $0.5 \mathrm{~g}$ of the chitosan sample was weighed into a porcelain boat, heated in an oven at $60^{\circ} \mathrm{C}$ for $1 \mathrm{hr}$ and reweighed after cooling until a constant weight was obtained. The moisture content was then calculated using equation (1)

$$
\% \text { moisture content }=\frac{\mathrm{W}_{\mathrm{b}}-\mathrm{W}_{\mathrm{a}}}{\mathrm{W}_{\mathrm{b}}} \times 100 \%
$$

$\mathrm{W}_{\mathrm{b}}=$ Weight of chitosan before heating and $\mathrm{W}_{\mathrm{a}}=$ Weight of chitosan after heating.

Ash Content of Chitosan: The ash content of the chitosan samples was determined using $2 \mathrm{~g}$ of chitosan sample placed into a crucible. The sample was heated in a furnace to $550{ }^{\circ} \mathrm{C}$ for 2 hours. The sample was allowed to cool and the weight of the ash residue was weighed, while the empty crucible was weighed separately. Equation (2) was employed to calculate the ash content.

$$
\text { Ash Content } \%=\frac{\text { Weight of the ash residue }(\mathrm{g})}{\text { Weight of the sample }(\mathrm{g})} \times 10
$$

Characterization of the Produced Chitosan: The produced chitosan was characterized for its functional groups; phase structure and morphology were investigated by the Fourier transform infrared spectroscopy (FTIRS), X-ray diffraction (XRD) and high resolution scanning electron microscopy (HRSEM). While the elemental compositions, particles size, size distributions, surface area/pore size, and thermal stability were determined using electron dispersion spectroscopy (EDS), dynamic light scattering (DLS), Brunauer Emmett Teller (BET) and Thermogravimetric analysis, respectively.

Characterization of Electroplating Wastewater: The $\mathrm{pH}$ and electrical conductivity of the collected electroplating wastewater were determined using multi-parameter analyzer C 3010 . While the total alkalinity, total hardness, chemical oxygen demand, total dissolved solids, and total amounts of nitrate, sulphate, phosphate, and chloride were determined using the standard methods described by the American Public Health Association [21]. These physicochemical properties of the wastewater were studied at the Regional Water Quality Laboratory, Federal Ministry of Water Resources, Minna Niger State, immediately after collection. The determination of $\mathrm{As}$ and $\mathrm{Cu}$ levels of the electroplating wastewater was performed using atomic absorption spectrophotometer, Bulk Scientific Model Accusys 211 USA. Cu metal level was determined using the air-acetylene, while that of As was done by manual gaseous hydride generation as described in the EZ arsenic test kit (HACH) [7, 22, 23].

Adsorption Studies of Heavy Metals: The adsorption efficiencies of the produced chitosan for the removal of the selected heavy metals (arsenic and copper) from electroplating wastewater were 
assessed at different contact times, adsorbent doses and temperatures via batch adsorption process. To investigate the effect of the adsorbent dosage, 5, 10, 15, 20 and $25 \mathrm{mg}$ of chitosan were individually interacted with $50 \mathrm{~cm}^{3}$ of electroplating wastewater in $250 \mathrm{~cm}^{3}$ corked Erlenmeyer flask for 60 minutes at stirring speed of $200 \mathrm{rpm}$ and room temperature. The effect of contact time was determined by adding a known dose $(25 \mathrm{mg})$ of chitosan to $50 \mathrm{~cm}^{3}$ of electroplating wastewater in $250 \mathrm{~cm}^{3}$ corked Erlenmeyer flask and agitating at $200 \mathrm{rpm}$ for different contact times $(15,30,45,60,75$ minutes) at room temperature. The effect of temperature on the adsorption process was investigated by adding 25 $\mathrm{mg}$ of chitosan to $50 \mathrm{~cm}^{3}$ of the electroplating wastewater in corked $250 \mathrm{~cm}^{3}$ conical flasks, with agitation of s200 rpm, different temperatures of 303, 318, 333, 348 and $363 \mathrm{~K}$ for 60 minutes, and an optimum adsorbent dosage at optimum contact time. After each investigation, the chitosan adsorbent was separated from the mixtures using centrifugation and the supernatants were analyzed for the residual concentrations of heavy metals using atomic absorption spectrophotometer (Bulk Scientific AAS: Model Accusys 211 USA).

Data Analysis: Equation (3) was used to determine the amount of metal ions adsorbed by chitosan adsorbent

$\mathrm{Q}=\frac{V\left(C_{0}-C_{e}\right)}{\mathrm{W}} \times 100$

where $C_{o}$ is the initial concentration $\left(\mathrm{mg} / \mathrm{dm}^{3}\right)$ of heavy metal ions in the electroplating wastewater before adsorption, $C_{e}$ is the concentration $\left(\mathrm{mg} / \mathrm{dm}^{3}\right)$ of the heavy metal ions in the filtrate after adsorption, $\mathrm{V}$ is the volume of adsorbate in $\mathrm{dm}^{3}, \mathrm{Q}$ is the amount of heavy metal ions adsorbed on chitosan in $\mathrm{mg} / \mathrm{g}$, and $\mathrm{R}$ is the adsorption percentage. The heavy metal removal efficiency $\mathrm{R}(\%)$ was calculated using Equation (4) expressed as follows

$$
\mathrm{R}(\%)=\frac{\left(C_{0}-C_{e}\right)}{C_{0}} \times 100
$$

\section{RESULTS AND DISCUSSION}

Table 1- Yield, moisture and ash contents of the extracted chitosan

\begin{tabular}{cc}
\hline Properties of chitosan & Values (\%) \\
\hline Yield of Chitosan & 15.40 \\
Moisture content of extracted chitosan & 2.94 \\
Ash content of extracted chitosan & 6.25 \\
\hline
\end{tabular}

The results of this study revealed that the obtained chitosan has percentage yield of $15.4 \%$ dry weight, off-white in colour, odourless and in a form of semi-crystalline powder. Previous work by Nouriet al [24] showed the percentage yield of extracted chitosan to be 6-13.5\%.

Among the factors that can affect the quality of chitosan produced is moisture content. Generally, good quality of chitosan produced after adequate deproteinization, demineralization and deacetylation processes should have a moisture content of less than $10 \%$ [25], because the higher water content in the chitosan structure, the faster damage of the polymer through hydrolysis reactions [26]. The results in Table 1 show that the moisture content of chitosan obtained in this study was $2.94 \%$, which indicates that the moisture content was low, hence it is of good quality and suitable for scientific and industrial applications. It was found that moisture content of chitosan in this study is lower compared to $9.34 \%$ of moisture content of chitosan obtained in the study published by Puvvada et al. [27] and also less than the $10 \%$ reported for commercial chitosan by Ghannam et al., [28]. Meanwhile, due to the hygroscopic nature of chitosan, it may yet absorb more moisture during storage.

From Table-1, the ash content of chitosan obtained in this study was $6.25 \%$. This value is lower compared to ash contents of $6.41 \%$ and $36.87 \%$ reported by Isa et al., [29] and Abdulkarim et al., [30] for chitosan prepared from Nigerian shrimp and mussel shell, respectively. However, the value is slightly higher than 5\% of ash content recommended for high-quality chitosan [31].

\section{Characterization of the Produced Chitosan}

Fourier Transforms Infrared Spectroscopy (FTIR) of Chitosan: Figure-2 demonstrates the FTIR spectrum of the produced chitosan. 


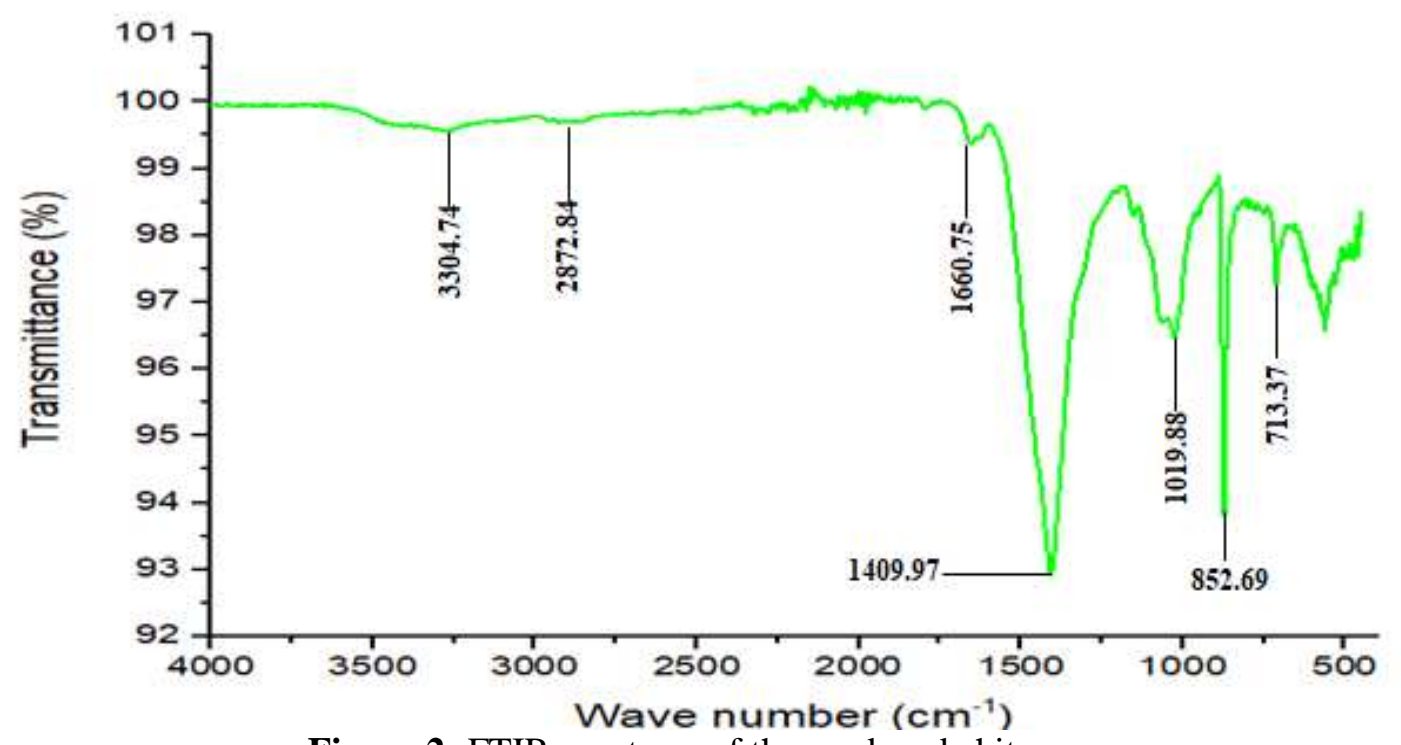

Figure 2- FTIR spectrum of the produced chitosan

The FTIR spectrum of the chitosan showed absorption peaks at 3304.74, 2872.84, 1660.75, $1409.97,1019.88,852.69$ and $713.37 \mathrm{~cm}^{-1}$. The absorption peak at $3304.74 \mathrm{~cm}^{-1}$ is attributed to the overlapped peaks of the N-H and O-H stretching vibration [32]. The absorbance peaks at $2872.84 \mathrm{~cm}^{-}$ ${ }^{1}, 1660.75 \mathrm{~cm}^{-1}$ and $1409.97 \mathrm{~cm}^{-1}$ indicate the $\mathrm{C}-\mathrm{H}$ stretching of polymeric link, $\mathrm{N}-\mathrm{H}$ in-plane bend, and $\mathrm{O}-\mathrm{H}$ deformation in-plane respectively [33]. The characteristic absorption peaks at 1033.81 and $852.69 \mathrm{~cm}^{-1}$ are assigned to $\mathrm{C}-\mathrm{O}$ stretching of $\mathrm{O}-\mathrm{H}$ groups due to deformation $[34,35]$. The peak observed at $713.37 \mathrm{~cm}^{-1}$ is assigned to $\mathrm{N}-\mathrm{H}$ wag amines [36].

X-Ray Diffraction (XRD) Pattern of the Extracted Chitosan: The XRD pattern of the produced chitosan is shown in Figure- 3, which reveals significant peaks at $2 \theta=10.110$ and 19.200 which are typical of semi-crystalline chitosan [37, 32]. These two peaks were related to crystal I and crystal II of chitosan structure [32] and were attributed to the high degree of crystallinity [38]. This high crystallinity development within the polymer can be due to its structural regularity, polarity, presence of hydrogen links and also the capacity to pack polymer chains [39]. However, Yen and Mau [40] reported that chitosan produced from fungi had two crystalline reflections at $9.7^{\circ}$ and $19.9^{\circ}$. On the other hand, in the case of shrimp chitosan, it was reported that it has two major peaks at $2 \theta=9.9$ to $10.7^{\circ}$ and 19.8 to $20.7^{\circ}$ [41]. The presence of other peaks in the diffractogram of chitosan can be attributed to other minerals present as components of the crab shells [42]. The crystallinity index (CI) of the chitosan, which was calculated using Equation (5), was obtained as shown in Table 2 to be $69.54 \%$.

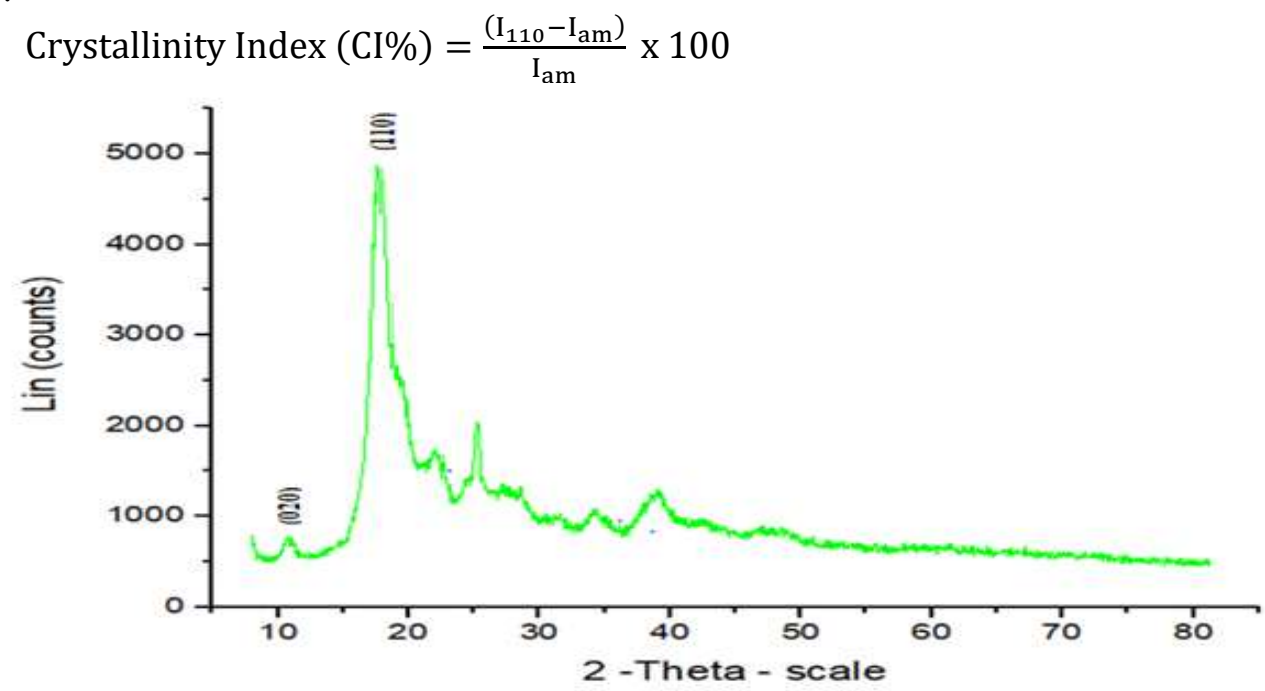

Figure 3-XRD Pattern of Extracted Chitosan 
Table 2-Crystallinity Index of the prepared Chitosan

\begin{tabular}{ccccc}
\hline & Peak position (20) & Counts & Intensity & Crystallinity Index (\%) \\
\hline \multirow{2}{*}{ Chitosan } & 10.11 & $697 / 4.2$ & $\mathrm{I}_{\mathrm{am}}=166$ & 69.54 \\
& 19.20 & $4851 / 8.9$ & $\mathrm{I}_{110}=545$ & \\
\hline
\end{tabular}

High Resolution Scanning Electron Micrograph (HRSEM) of Produced Chitosan: The surface morphology of the produced chitosan was studied by HRSEM. The micrograph of chitosan is shown in Figure-4.

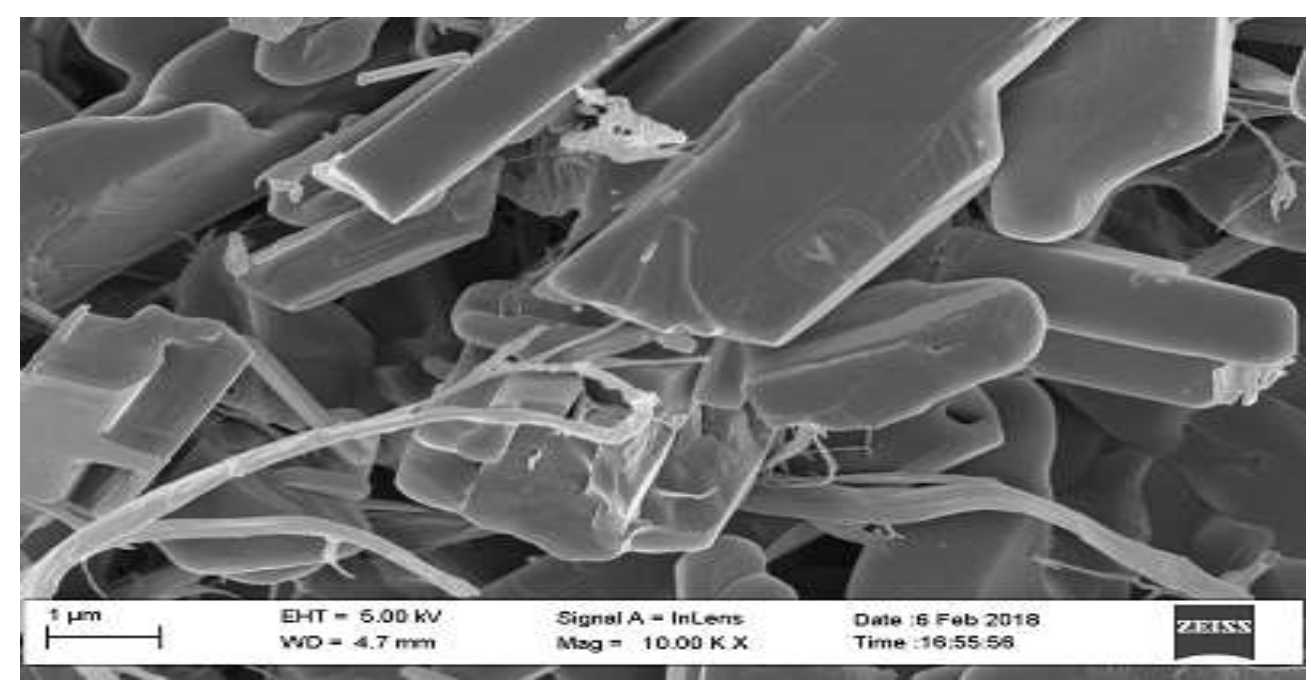

Figure 4-HRSEM Image of produced chitosan

The HRSEM image in Figure-4 reveals that chitosan particles have a needle-like crystalline structure with a smooth surface. In a study by Krishnaveni and Ragunathan [43] the morphology of chitosan prepared from $F$. solani also portrayed a needle-shaped semi-crystalline structure with a smooth surface.

Electron Dispersive Spectra (EDS) of Chitosan: The EDS results, which revealed the elemental composition present in the produced chitosan, is presented in Figure-5.

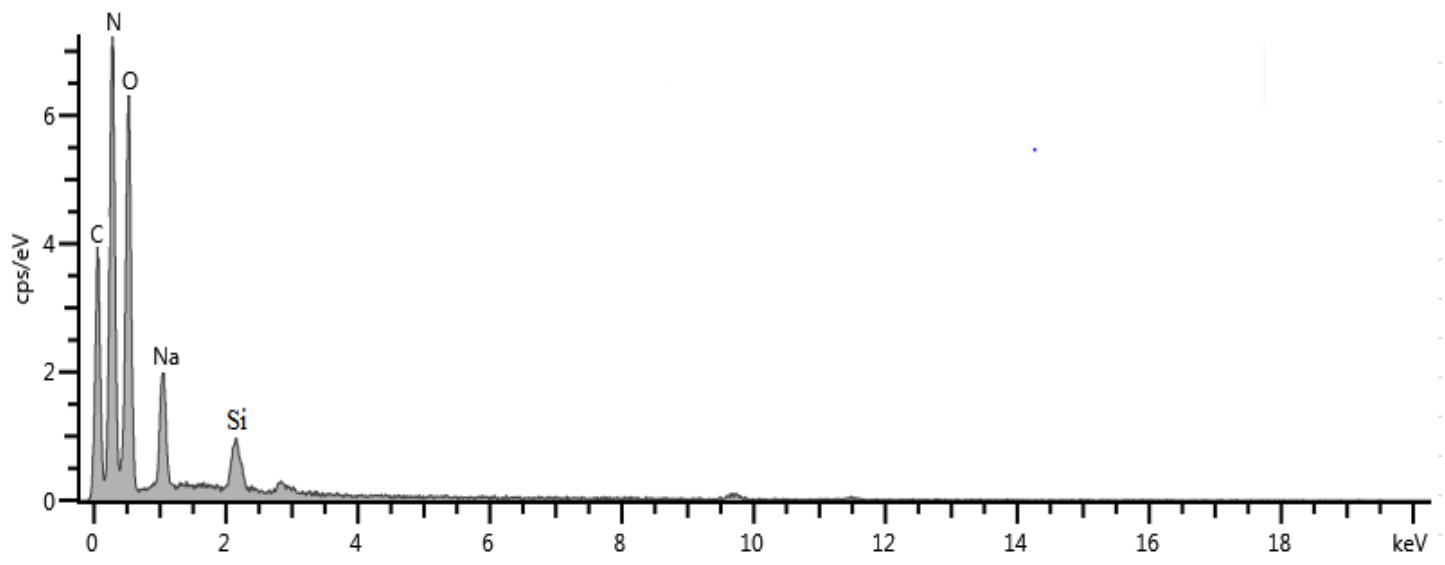

Figure 5- EDS Spectrum for Chitosan

The spectrum shows the presence of key elements (carbon, nitrogen and oxygen) that form the chemical structure of chitosan as a biopolymer. Hydrogen is an elemental component of chitosan, with only K shell is not detectable with EDS [44]. The presence of strong signals of $\mathrm{Na}$ is attributed to the strong bond formed by $\mathrm{Na}$ as one of the micronutrients commonly found in chitosan [45]. Also, the 
presence of a signal similar to that of silicon may be attributed to interferences of the debris of siliconlithium detector as a component of the HRSEM machine used [46].

Dynamic Light Scattering of Chitosan: The particle size distribution histogram of the produced chitosan is shown inFigure-6.

\section{Size Distribution by Intensity}

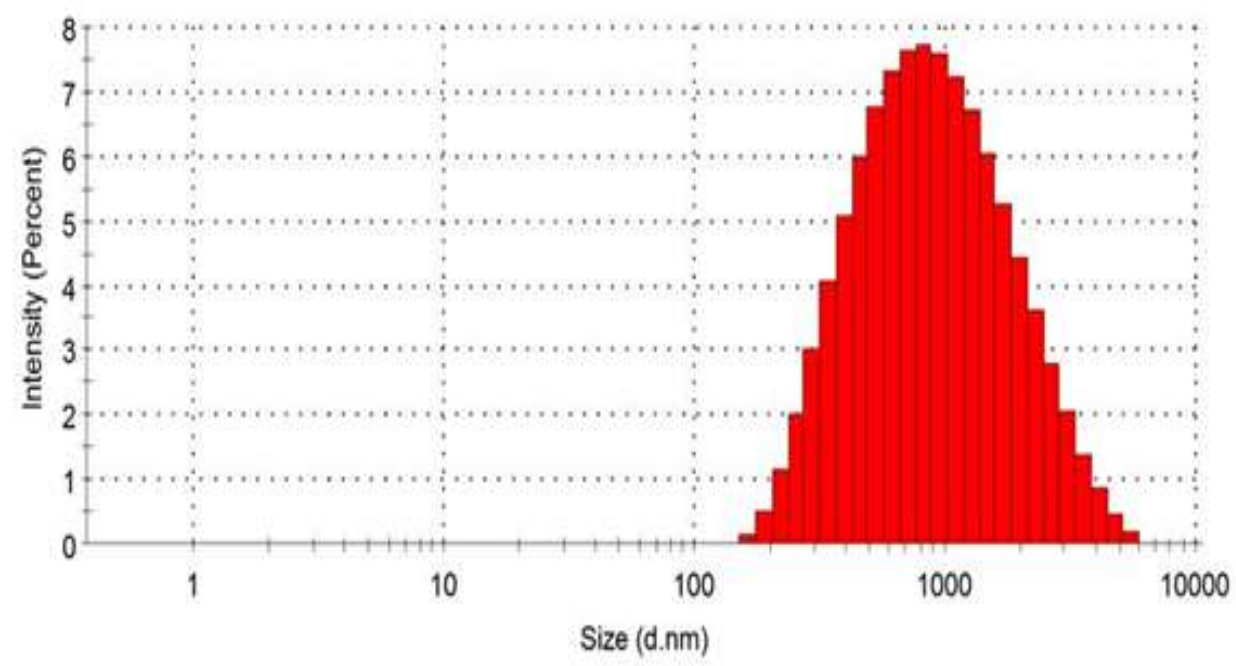

Figure 6- Particle size distribution histogram of produced chitosan

The distribution histogram of chitosan showed the presence of only one peak Figure- 6 and $100 \%$ of particles size falling within the range of $100-10000 \mathrm{~nm}$, with an average particle size of $729 \mathrm{~nm}$. This average particles size is higher than the $394.8 \mathrm{~nm}$ size obtained by Chattopadhyay and Milind [47], which may be attributed to the absence of electrostatic hindrance to the repulsion between protonated amino groups [48]. Also, the polydispersity index (PDI) value for the produced chitosan in this study is 0.275 , which is within the range of $0.1-0.4$ typically indicates that the chitosan particles are moderately polydisperse [49].

BET of Chitosan: Surface texture characterization of the prepared chitosan was carried out by nitrogen gas adsorption-desorption at $77 \mathrm{~K}$.

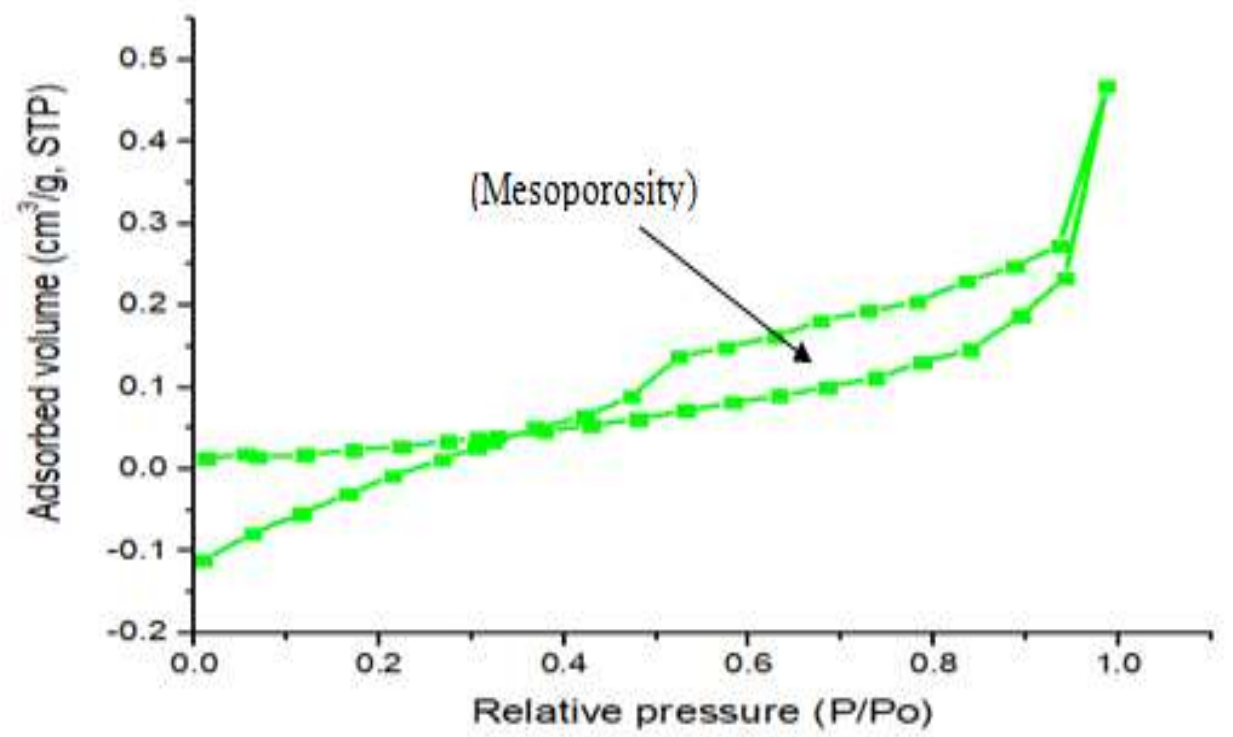

Figure 7- Nitrogen adsorption/desorption isotherms of the produced chitosan 


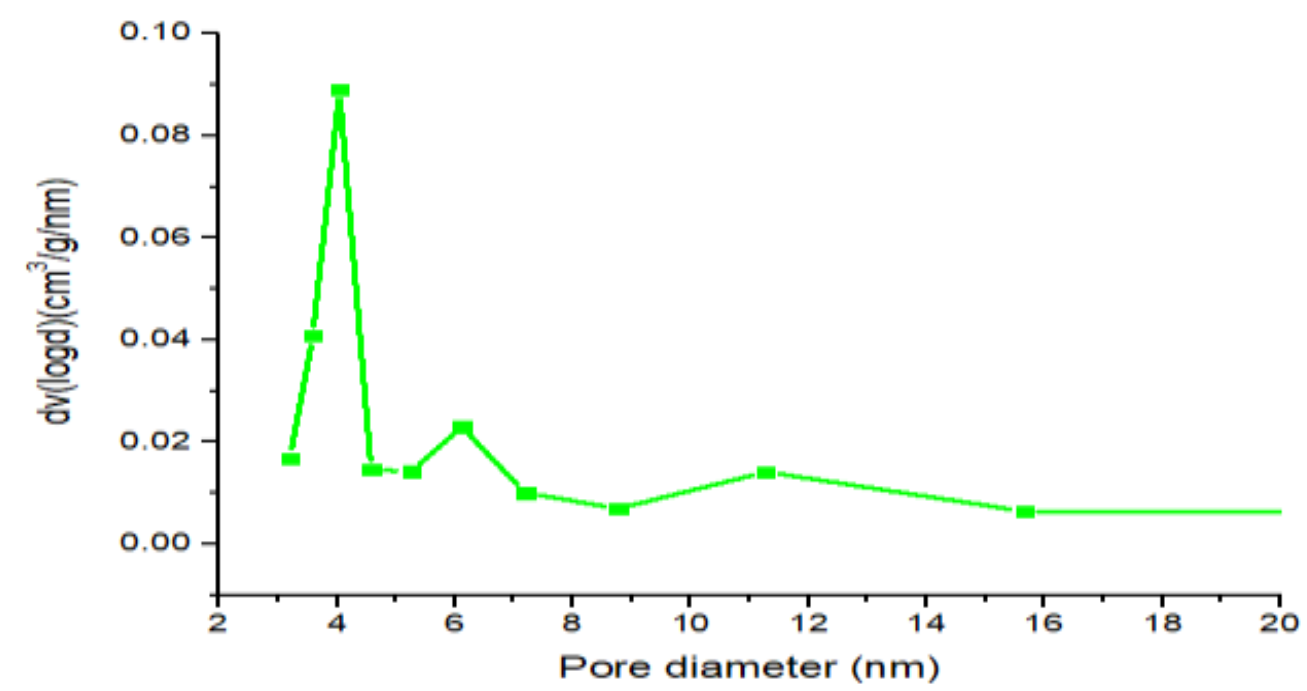

Figure 8- Pore-size distribution curve for the produced chitosan

Figure-7 presents the nitrogen adsorption/desorption isotherms measured at $77 \mathrm{~K}$ for the produced chitosan. The shape of the isotherm corresponds to the Type III adsorption isotherm, based on the International Union of Pure and Applied Chemistry (IUPAC) classification. This type of isotherm is commonly observed in mesoporous materials, of which the sharp increase of the adsorbed quantity at high relative pressure indicates that the available mesoporous volume is occupied. The presence of mesopores is confirmed by the diagram of the pore size distribution (Figure- 8), which was obtained by the adsorption portion of the isotherm using the $\mathrm{BJH}$ method. According to the IUPAC recommendations, the mesopores are defined as pores with a diameter between 2 and $50 \mathrm{~nm}$. Therefore, the produced chitosan is mesoporous in nature. The result of BET analysis revealed that the surface area, pore volume and pore size of the produced chitosan are $12.67 \mathrm{~m}^{2} / \mathrm{g}, 0.0266 \mathrm{~cm}^{3} / \mathrm{g}$ and $4.035 \mathrm{~nm}$, respectively. The surface area of chitosan obtained in this study is higher compared to $0.1698 \mathrm{~m}^{2} / \mathrm{g}$ and $5.5156 \mathrm{~m}^{2} / \mathrm{g}$ obtained by Thien et al., [50] for bare chitosan and fully deacetylated chitosan, respectively.

Thermal Gravimetric Analysis (TGA): Thermal history of the produced chitosan was determined using thermogravimetric analysis (TGA) in the temperature range from room temperature to $600^{\circ} \mathrm{C}$ and the results are shown as a thermogram in Figure-9.

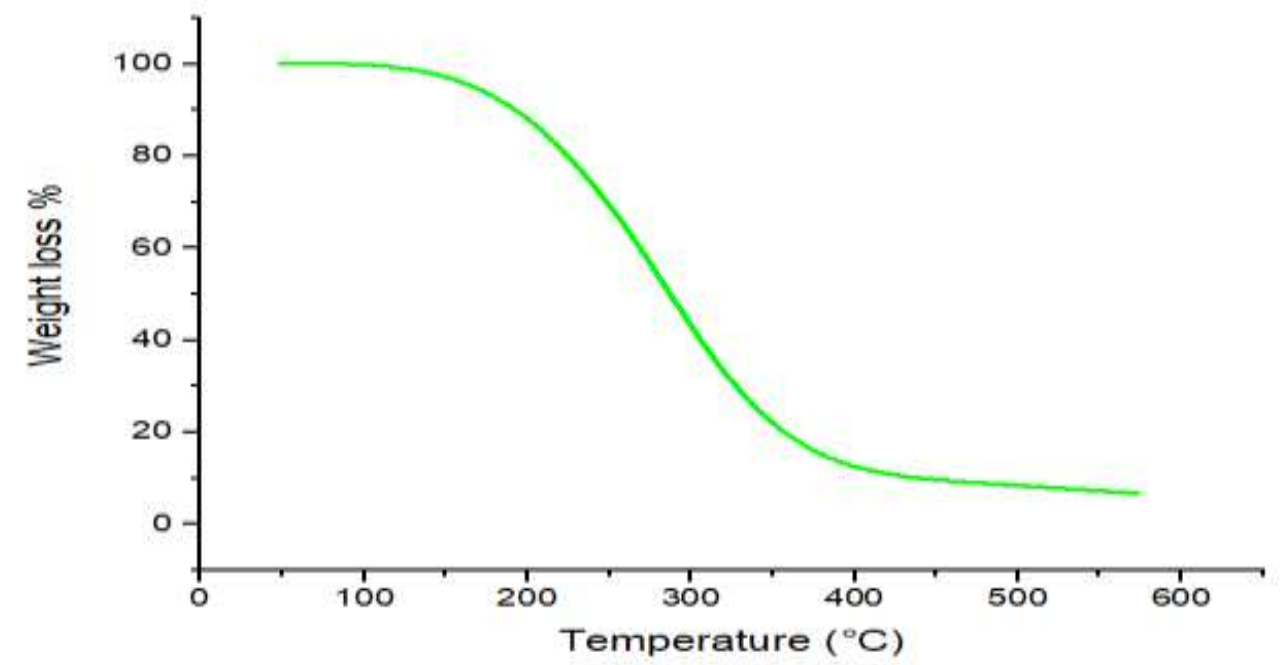

Figure 9- Thermogram of the produced chitosan

The obtained thermogram for chitosan, shown in Figure-9, reveals that chitosan undergoes thermal degradation which involved water loss from the dehydration of polymer compounds, disintegrations of intermolecular interaction and complete volatilization. The weight loss began near $48.55^{\circ} \mathrm{C}$, as observed in Figure- 9. The weight loss in this region may be due to the loss of $2.94 \%$ moisture from 
the sample. A sharp weight loss of about $86.67 \%$ is due to loss of $\mathrm{CO}_{2}$ that occurred between 143 $390^{\circ} \mathrm{C}$ [51]. From around $400^{\circ} \mathrm{C}$ up to about $573^{\circ} \mathrm{C}$, there was no observable weight loss and hence, at a temperature of $573^{\circ} \mathrm{C}$, the ash content of chitosan was calculated to be $6.25 \%$.

\section{Adsorption Parameters}

Effect of Contact Time on Adsorption: Figure-9 shows the effect of contact time on the percentage removal of $\mathrm{As}$ and $\mathrm{Cu}$ from electroplating wastewater using chitosan.

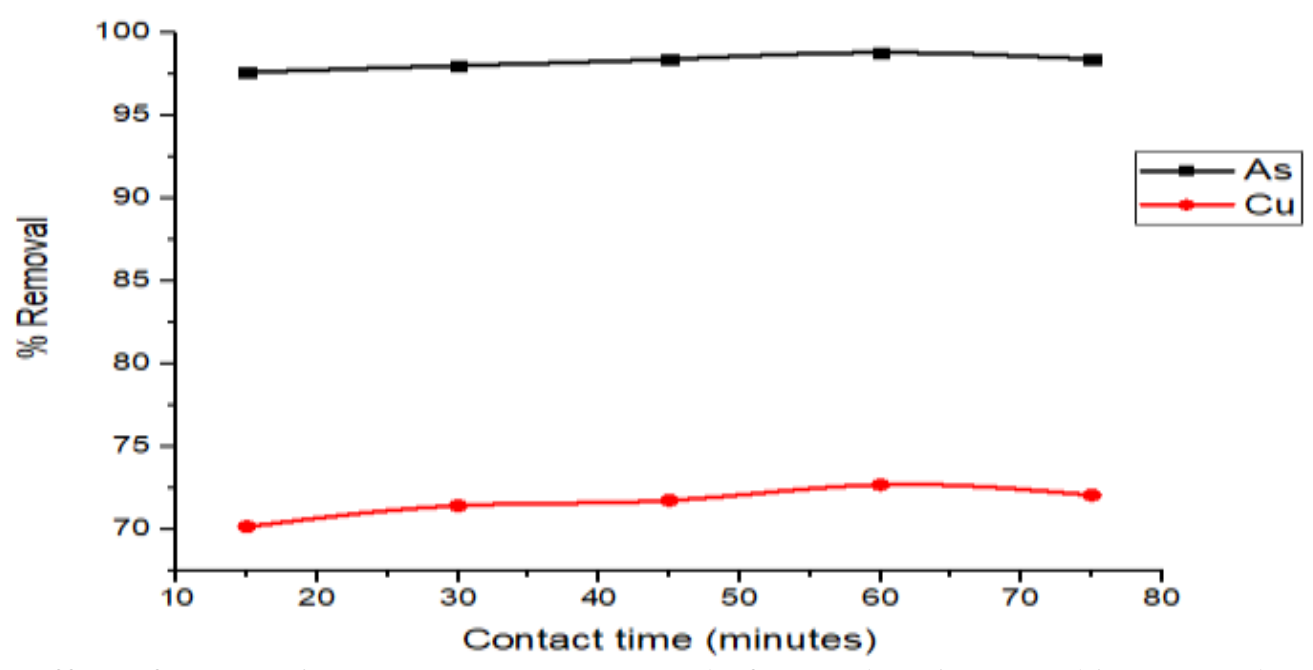

Figure 9: Effect of contact time on percentage removal of As and $\mathrm{Cu}$ ions on chitosan (Volumeof electroplating wastewater $=50 \mathrm{~cm}^{3}$, adsorbent dosage $=25 \mathrm{mg}$, temperature $=303 \mathrm{k}$, stirring speed $=$ 200rpm).

In Figure-9, it is noticed that the percentage removal of $\mathrm{As}$ and $\mathrm{Cu}$ ions increases with the increase in contact time up till an optimum time of 60 minutes. The rapid initial adsorption rate may be due to the high driving force within the adsorbate causing the quick transfer mechanism between the adsorbed metal ions and the binding site of the adsorbent. In Figure- 9, the amount of As and $\mathrm{Cu}$ ions sequestered at the optimum contact time of 60 minutes were $98.81 \%$ and $72.70 \%$, respectively. It is obvious that at an initial contact time of 15 minutes the amount of the adsorbed Aswas greater than that of $\mathrm{Cu}$. This may be attributed to the fact that As with smaller ionic radii transfers faster than $\mathrm{Cu}$ which has larger ionic radii.

Effects of Adsorbent Dose: The dosage of adsorbent has a significant consequence on the adsorption process and it describes the capacity of the adsorbent through the number of active binding sites accessible to remove heavy metal ions. The effects of adsorbent dose on the percentage removal of As and $\mathrm{Cu}$ ions are shown in Figure- 10.

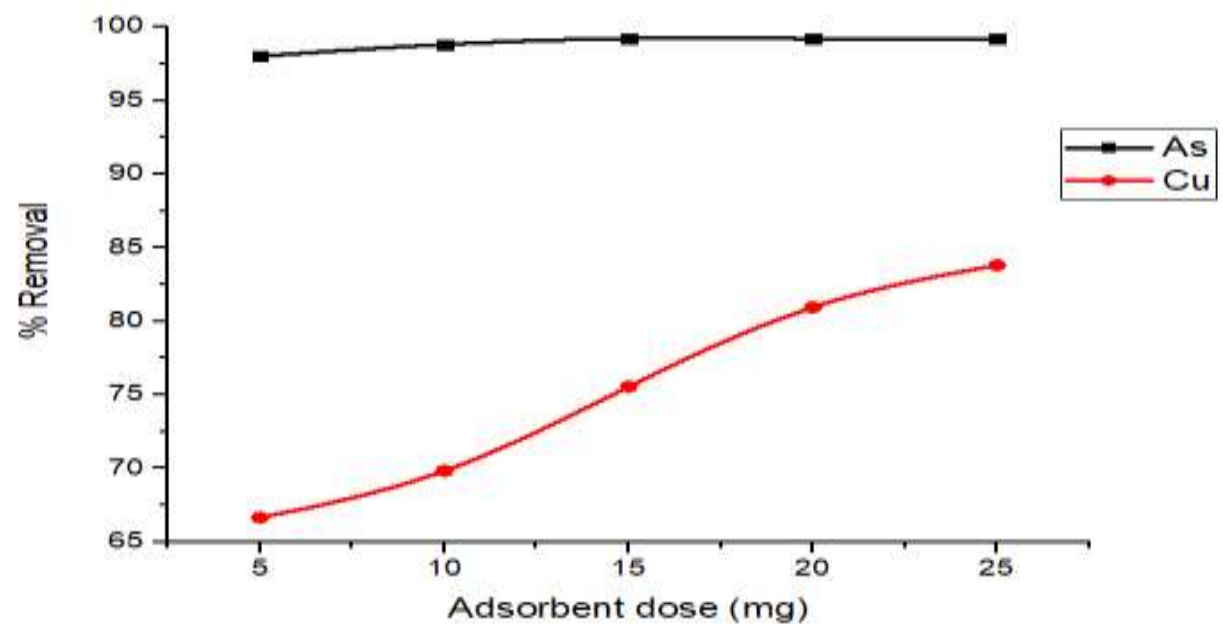

Figure 10-Effect of adsorbent dose on percentage removal of $\mathrm{As}$ and $\mathrm{Cu}$ ions (Volume of electroplating wastewater $=50 \mathrm{~cm}^{3}$, contact time 60 minute, temperature $=303 \mathrm{k}$, stirring speed $=$ 200rpm). 
Figure-10 shows the effects of adsorbent dosages on As ions removal from electroplating wastewater. The adsorption of As ions is observed to increase as the dose of adsorbent is increased from 5 to $25 \mathrm{mg}$. The optimum adsorption of As on the chitosan was $99.21 \%$ using a dose of $15 \mathrm{mg}$. A further increase of the adsorbent dosage beyond these optimum doses showed no more removal of As ions on the adsorbent. Thus, the early attainment of optimum adsorption of As ions by chitosan may be due to the availability of more binding sites in the adsorbent. Figure-10 also shows the effects of adsorbent dosage on the adsorption of $\mathrm{Cu}$ ions using chitosan. Percentage removals of $\mathrm{Cu}$ ions continue to increase as adsorbent doses increase. This trend may be because of an increase in the number of binding sites at higher adsorbent dosage. This shows that the percentage removal of $\mathrm{Cu}$ ions is determined by the number of accessible binding sites [52]. Figure also 10 shows that at $25 \mathrm{mg}$, the optimum percentage removal of $\mathrm{Cu}$ ions was achieved at $83.81 \%$. However, a high increase in the removal of $\mathrm{Cu}$ ions beyond optimum adsorbent dose may be attributed to a strong interaction between the adsorbate and adsorbent.

\section{Effect of Temperature on Adsorption}

The effects of temperature on the removal of $\mathrm{As}$ and $\mathrm{Cu}$ by chitosan were studied. The temperature of the electroplating wastewater varied in the range of $300-363 \mathrm{~K}$ while other parameters, namely adsorbent dosage and contact time, were kept constant at $25 \mathrm{mg}$ and 60 minutes, respectively, at a constant stirring speed of $200 \mathrm{rpm}$. The effect of temperature on the percentage removal of each metal is shown in Figure-11.

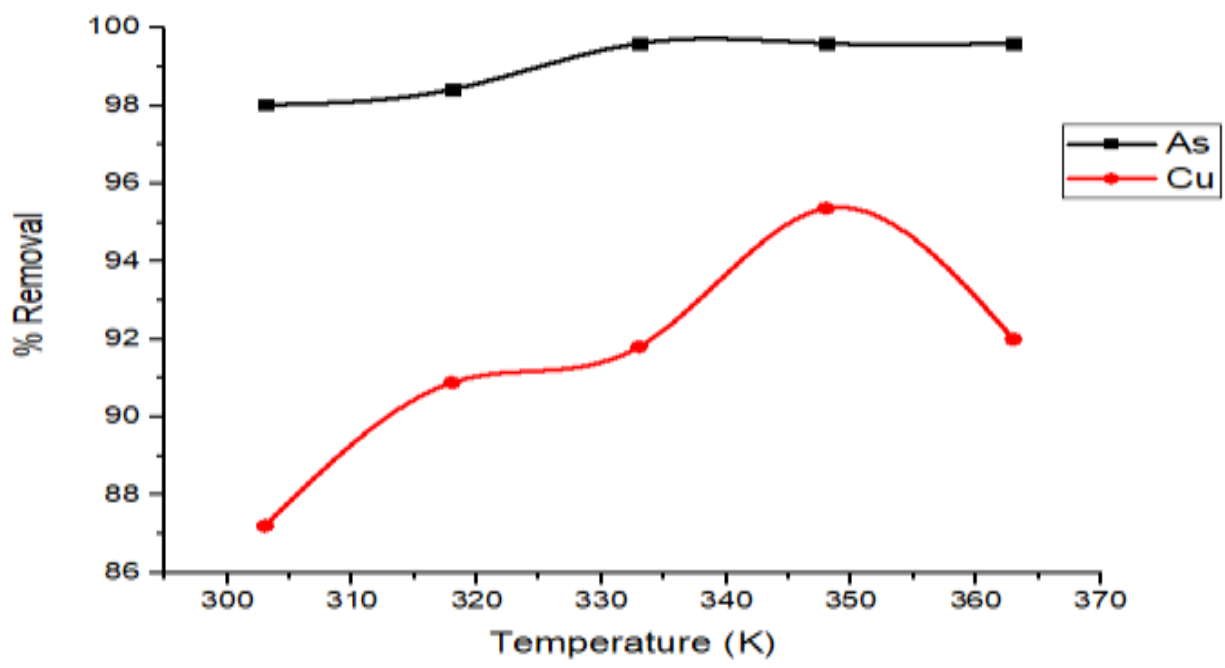

Figure 11-Effect of Temperature on percentage removal of As and $\mathrm{Cu}$ ions ((Volume of electroplating wastewater $=50 \mathrm{~cm}^{3}$, adsorbent dosage $=25 \mathrm{mg}$, contact time $=60$ minutes, stirring speed $=200 \mathrm{rpm}$ ).

The effect of temperature upon adsorption of $\mathrm{As}$ and $\mathrm{Cu}$ ions were studied on the variation of temperature from $303 \mathrm{~K}$ to $363 \mathrm{~K}$. It was observed from this study that the percentage removal of As and $\mathrm{Cu}$ ions on chitosan continues to increase until temperatures of $333 \mathrm{~K}$ and $348 \mathrm{~K}$, respectively, where the maximum percentage removal of $99.60 \%$ and $95.37 \%$ were achieved for $\mathrm{As}$ and $\mathrm{Cu}$, respectively. At these optimum temperatures, adsorption equilibrium between bulk phases and adsorbing surfaces of the adsorbent is reached. From Figure-11, at an initial temperature of $303 \mathrm{~K}$, adsorption was very fast such that $98.02 \%$ of As and $87.21 \%$ of $\mathrm{Cu}$ were adsorbed on chitosan. The adsorption became slow later until the optimum temperatures of $333 \mathrm{~K}$ and $348 \mathrm{~K}$ for As and $\mathrm{Cu}$ ions, respectively, were reached. This scenario may be attributed to the fact that as temperature increases, sufficient energy is being provided for the metal ions to reach the activation energy necessary to quickly diffuse at a high rate to the active sites on the adsorbent available for binding.

\section{Adsorption Isotherm for As and Cu ions Removal from Electroplating Wastewater}

In this study, three isotherm models (Jovanovic, Freundlich and Temkin) were employed. The data obtained from the adsorption studies were used to plot isotherms in their liner form to calculate the model constants, standard error and correlation coefficients $\left(\mathrm{R}^{2}\right)$. Equations 6, 7 and 8 represent Freundlich, Jovanovic and Temkin isotherm models, respectively. 
Table 3-Isotherm model parameters for the adsorption of As and $\mathrm{Cu}$ using Chitosan

\begin{tabular}{ccccccccc}
\hline Jovanovic & As & $\mathbf{C u}$ & Freundlich & As & $\mathbf{C u}$ & Temkin & As & Cu \\
\hline $\mathrm{K}_{\mathrm{j}}$ & 0.400 & 0.348 & $\mathrm{~K}_{\mathrm{f}}$ & 6.033 & 6.402 & $\mathrm{~K}_{1}$ & -0.059 & -0.620 \\
$\mathrm{q}_{\max }$ & 6.325 & 7.907 & $\mathrm{n}$ & - & - & & $3.6 \times 10^{-}$ & $3.5 \times$ \\
$\mathrm{R}^{2}$ & 0.999 & 0.999 & $\mathrm{R}^{2}$ & 0.992 & 0.959 & $\mathrm{R}^{2}$ & 0.993 & 0.966 \\
\multirow{2}{*}{ Std error } & $1.1 \mathrm{X}$ & \multirow{2}{*}{0.001} & Std error & 0.001 & 0.008 & $\begin{array}{c}\text { Std } \\
\text { error }\end{array}$ & 0.005 & 0.049 \\
\hline
\end{tabular}

*Std error $=$ standard error

From Table-3, Regression coefficients $\left(\mathrm{R}^{2}\right)$ and standard error for all the three isotherm models show that the adsorption isotherm data for $\mathrm{As}$ and $\mathrm{Cu}$ best fit Jovanovic isotherm model for the removal of these metal ions under investigation using chitosan. Therefore, the adsorptions of As and $\mathrm{Cu}$ metal ions in this study can be said to have taken place more on homogenous sites with monolayer coverage of metal ions on the outer surfaces of the adsorbent, along with some mechanical contacts between the metal ions and adsorbent as well as a competition for binding sites among the metal ions.

From Table-3, the increase in the values of the Freundlich constant $\left(\mathrm{K}_{\mathrm{f}}\right)$, as adsorption capacities of chitosan for the metal ions, is in the order of $\mathrm{Cu}>\mathrm{As}$. The higher adsorption capacity of chitosan for $\mathrm{Cu}$ as compared to As may be attributed to its greater adsorption affinity toward chitosan [53].

Temkin isotherm Model is a kind of isotherm model which considers the existence of interactions between adsorbents and adsorbents-like metal ions and assumes that the free energy of adsorption is a function of the surface coverage [54]. From the linear form of the Temkin model $\left(\mathrm{q}_{\mathrm{e}}=\mathrm{K}_{1} \ln \mathrm{K}_{2}+\right.$ $\mathrm{K}_{1} \ln \mathrm{C}_{\mathrm{e}}$ ), a plot of $\mathrm{q}_{\mathrm{e}}$ versus $\operatorname{lnC}_{\mathrm{e}}$ makes the calculation of constants $\mathrm{K}_{2}$ and $\mathrm{K}_{1}$ possible. The constant $\mathrm{K}_{1}$ is associated with heat of adsorption in $\mathrm{J} / \mathrm{mol}$. If $\mathrm{K}_{1}$ has a negative value, this implies that the adsorption process is exothermic. Otherwise, if it has a positive value, is the process is endothermic. Negative $\mathrm{K}_{1}$ values in Table 3 show that the removal of $\mathrm{As}$ and $\mathrm{Cu}$ ions in this study is an exothermic process. The order of decrease in $\mathrm{K}_{1}$ using chitosan was $\mathrm{As}>\mathrm{Cu}$. This implies that arsenic ions adsorption by chitosan releases greater energy than that of $\mathrm{Cu}$ ions.

$\mathrm{K}_{2}$ is the equilibrium binding constant equivalent to the maximum binding affinity, which is the strength of the binding interaction between a single individual molecule and ligands. The larger the $\mathrm{K}_{2}$ value, the more strongly the target species and ligands are attracted to and bind to one another. In this study, the orders of decrease in $\mathrm{K}_{2}$ of chitosan is $\mathrm{Cu}>\mathrm{As}$. This shows that chitosan has higher binding affinity for $\mathrm{Cu}$ as compared to As ions. This higher binding affinity constant observed for $\mathrm{Cu}$ implies that the chitosan has stronger interaction and attraction for $\mathrm{Cu}$ due to its higher electronegativity [55].

\section{Adsorption kinetic for As and $\mathrm{Cu}$ ions removal from electroplating wastewater}

Kinetic Models of Heavy Metals Adsorption: In this study, the rate and mechanism of adsorption of As and $\mathrm{Cu}$ ions onto chitosan were analysed by applying three kinetics models to the experimental data. These models include Pseudo-first order, Pseudo-second order and Elovich. Correlation coefficient $\left(\mathrm{R}^{2}\right)$ and standard error (S.E) were used to measure the goodness-of-fit of the selected kinetic models. The values of the rate constants and other parameters obtained from the slopes and intercepts of the plots are shown in Table 4.

Table 4-Kinetic parameters for adsorption of $\mathrm{As}$ and $\mathrm{Cu}$ from electroplating wastewater using chitosan

\begin{tabular}{|c|c|c|c|c|c|c|c|c|c|c|}
\hline & \multicolumn{3}{|c|}{ Pseudo first -order } & \multicolumn{3}{|c|}{ Pseudo-second order } & \multicolumn{4}{|c|}{ Elovich } \\
\hline $\begin{array}{c}\text { Met } \\
\text { al }\end{array}$ & $\mathrm{K}_{1} \underset{1}{\left(\min ^{-}\right.}$ & $\mathbf{R}^{2}$ & $\begin{array}{l}\text { Standard } \\
\text { error }\end{array}$ & $\begin{array}{l}\mathbf{K}_{\mathbf{2}}(\mathrm{g} / \mathrm{m} \\
\mathrm{gmin})\end{array}$ & $\mathbf{R}^{2}$ & $\begin{array}{c}\text { Standa } \\
\text { rd } \\
\text { error }\end{array}$ & $\Delta$ & $\Theta$ & $\mathbf{R}^{2}$ & $\begin{array}{l}\text { Standar } \\
\text { d error }\end{array}$ \\
\hline As & $1.88 \times 10^{-4}$ & $\begin{array}{c}0.94 \\
2\end{array}$ & 0.001 & $\begin{array}{c}7.60 x \\
10^{-5}\end{array}$ & $\begin{array}{c}0.94 \\
2\end{array}$ & 0.0005 & $\begin{array}{c}57.0 \\
5\end{array}$ & $\begin{array}{c}1.80 \mathrm{x} \\
10^{58}\end{array}$ & $\begin{array}{c}0.95 \\
4\end{array}$ & 0.0028 \\
\hline $\mathrm{Cu}$ & $5.33 \times 10^{-}$ & $\begin{array}{c}0.91 \\
8\end{array}$ & 0.004 & $\begin{array}{c}2.40 \mathrm{x} \\
10^{-4}\end{array}$ & $\begin{array}{c}0.91 \\
8\end{array}$ & 0.0044 & $\begin{array}{c}21.7 \\
2\end{array}$ & $\begin{array}{c}2.27 \mathrm{x} \\
10^{18}\end{array}$ & $\begin{array}{c}0.97 \\
2\end{array}$ & 0.0057 \\
\hline
\end{tabular}


From Table-4, Regression coefficients $\left(\mathrm{R}^{2}\right)$ and standard error for all the three kinetic models show that the adsorption kinetic data for $\mathrm{As}$ and $\mathrm{Cu}$ ions best fit Pseudo-second order kinetic model under the current investigation using chitosan. Thus, Pseudo-second order kinetic model best explained the rate of adsorptions of $\mathrm{As}$ and $\mathrm{Cu}$ ions as compared to the other kinetic models, due to its very high $\mathrm{R}^{2}$ and very low standard values. Therefore, the entire rate-determining step of adsorptions of both metal ions in this study is controlled by chemisorption which involves the contribution or sharing of electrons between the metal ions and functional groups $\left(-\mathrm{OH}\right.$ and $\left.-\mathrm{NH}_{2}\right)$ in the chitosan $[56,57]$. Also, in this study, the order of fitness of adsorption kinetic data on the pseudo second order model is $\mathrm{As}>\mathrm{Cu}$. Meanwhile, the pseudo-second-order rate constants $\mathrm{K}_{2}(\mathrm{~g} / \mathrm{mg} / \mathrm{min})$ were found to be significant, which supports that the $\mathrm{As}$ and $\mathrm{Cu}$ metal ions uptake from electroplating wastewater onto the chitosan was fast and favorable. This outcome is in agreement with the results reported in studies carried out by Kowanga et al.,[58] and Elsay et al., [59].The values for correlation coefficients and standard errors for Elovich model shown in Table 4 suggest that the equilibrium data for the adsorption of $\mathrm{Cu}$ ions onto chitosan could not be well described by Elovich model and, thus, the adsorption of these metal ions was not a multilayer adsorption[60].

Thermodynamic Studies of As and Cu ions Adsorption: The nature of the adsorption process can be obtained from the thermodynamic study. The parameters to determine are the changes in the Gibbs energy $\left(\Delta \mathrm{G}^{\mathrm{o}}\right)$, enthalpy $\left(\Delta \mathrm{H}^{\mathrm{o}}\right)$, and entropy $\left(\Delta \mathrm{S}^{\mathrm{o}}\right)$. The change in $\Delta \mathrm{G}^{\mathrm{o}}$ indicates the spontaneity of a chemical reaction. Reactions only occur spontaneously if $\Delta \mathrm{G}^{\circ}$ at a given temperature is negative. The Van't Hoff equation can be used to calculate the Gibbs free energy change $\Delta \mathrm{G}$ of the adsorption process [61]

$\Delta \mathrm{G}^{\circ}=-\mathrm{RTInK}$

$\mathrm{K}=\frac{q_{e}}{c_{e}}$

The relationship between enthalpy change $(\Delta \mathrm{H})$ of adsorption, entropy change $(\Delta \mathrm{S})$ and Gibbs free energy is presented as in the equation:

$\Delta \mathrm{G}^{\circ}=-\mathrm{RTInK}=\Delta \mathrm{H}-\mathrm{T} \Delta \mathrm{S}$

$\operatorname{In} K=\frac{\Delta S}{R}-\frac{\Delta H}{R T}$

Where $\mathrm{K}$ in Equation (13) is the equilibrium constant of Van't Hoff equation and $\mathrm{R}$ is the universal gas constant $(8.314 \mathrm{~J} / \mathrm{mol} / \mathrm{K})$. A plot of $\mathrm{In} \mathrm{K}$ against $1 / \mathrm{T}$ is a straight line, while $\Delta \mathrm{H}$ and $\Delta \mathrm{S}$ can be determined from intercept and slope, respectively. In this study, Table 5 shows the thermodynamic parameters for adsorption of $\mathrm{As}$ and $\mathrm{Cu}$ ions from electroplating wastewater using chitosan.

Table 5-Thermodynamic parameters of $\mathrm{As}$ and $\mathrm{Cu}$ ions adsorption using chitosan

\begin{tabular}{ccccc}
\hline Metal & Temperature ${ }^{\mathbf{0}} \mathbf{K}$ & $\boldsymbol{\Delta} \mathbf{H}\left(\mathbf{k J m o l}^{\mathbf{- 1}}\right)$ & $\boldsymbol{\Delta} \mathbf{S}\left(\mathbf{j m o l}^{\mathbf{- 1}} \mathbf{k}^{\mathbf{- 1}}\right)$ & $\boldsymbol{\Delta} \mathbf{G}\left(\mathbf{k J m o l} \mathbf{~}^{\mathbf{- 1}}\right)$ \\
\hline As & 303 & 0.273 & $6.507 \times 10^{-3}$ & -1.696 \\
& 318 & & & -1.790 \\
& 333 & & & -1.908 \\
& 348 & & & -1.994 \\
$\mathrm{Cu}$ & 363 & 0.781 & $7.376 \times 10^{-3}$ & -2.080 \\
& 303 & & & -1.401 \\
& 318 & & & -1.607 \\
& 333 & & & -1.695 \\
& 348 & & & -1.868 \\
& 363 & & & -1.894 \\
\hline
\end{tabular}

Generally, the positive values of $\Delta \mathrm{H}^{\circ}$ for the adsorption of $\mathrm{As}$ and $\mathrm{Cu}$ ions by chitosan show that their adsorption is endothermic [62]. This implies that the heat adsorbed was used to break chemical bonds to free the metal ions. While the positive values of $\Delta \mathrm{S}$ obtained for both $\mathrm{As}$ and $\mathrm{Cu}$ ions adsorption suggest increased degree of randomness at the solid/solution interface during the adsorption process [63].

In general, from Table 5, the values of $\Delta \mathrm{G}^{\circ}$ for both $\mathrm{As}$ and $\mathrm{Cu}$ ions, at all tested temperatures on chitosan, were negative, which indicates that the adsorption processes were feasible and spontaneous 
in nature and implies a greater driving force of adsorption, resulting in high adsorption . The $\Delta \mathrm{G}^{\circ}$ values become more negative with the increase in temperature, indicating that the adsorption process becomes less favorable at high temperatures [64]. This further supports the earlier observation that the percentage removal of each metal ion becomes smaller as temperature increases.

\section{CONCLUSIONS}

In conclusion, chitosan was produced via three stages; proteinization, demineralization and deacetylation, and subsequently used for the removal of $\mathrm{As}$ and $\mathrm{Cu}$ ions from electroplating wastewater. The produced chitosan was characterized using standard analytical techniques. The HRSEM results showed needle-like morphology. The FTIR result of the produced chitosan indicated the presence of $-\mathrm{OH}$ and $-\mathrm{NH}_{2}$ groups which are the main groups that constitute the active sites of the biopolymer. The adsorption efficiency of chitosan for the removal of $\mathrm{As}$ and $\mathrm{Cu}$ ions from the electroplating wastewater was studied and it was found to depend on contact time, adsorbent dose and temperature. The removal percentage of the metal ions was in the order of $\mathrm{As}>\mathrm{Cu}$ and the performance of the chitosan adsorbent were functional groups-specific rather than the surface area-specific. Also, the adsorption isotherm and kinetic data for $\mathrm{As}$ and $\mathrm{Cu}$ were best fitted to Jovanovic isotherm and pseudo-second order models, respectively. The adsorption process of $\mathrm{As}$ and $\mathrm{Cu}$ ions from the electroplating wastewater was possible, spontaneous and endothermic in nature. The study confirmed that the chitosan was extracted from crab shells and the simple extraction method of chitosan can be applied as an effective means for solving environmental and economic problems caused by the shell wastes.

\section{Acknowledgement}

The authors acknowledge the financial support from Tertiary Education Trust Fund (TETFund) Nigeria with grant number TETFUND/FUTMINNA/2016-2017/6 ${ }^{\text {th }} B R P / 05$ through the Institution Based Research (IBR) of the Federal University of Technology, Minna, Nigeria.

\section{Competing Interest Statement}

The authors declare no conflict of interest

\section{References}

1. Fashola, M. O., Ngole-Jeme, V. M. And Babalola, O. O. 2016. Heavy Metal Pollution from Gold Mines: Environmental Effects and Bacterial Strategies for Resistance. International journal of environmental research and public health, 13(11): 1047. doi: 10.3390/ijerph13111047.

2. Bernard E. Igiri, Stanley I. R. Okoduwa, Grace O. Idoko, Ebere P. Akabuogu, Abraham O. Adeyi, and Ibe K. Ejiogu, 2018. "Toxicity and Bioremediation of Heavy Metals Contaminated Ecosystem from Tannery Wastewater: A Review," Journal of Toxicology, vol. 2018, Article ID 2568038, 16 pages,. https://doi.org/10.1155/2018/2568038

3. Ayangbenro, A. S. and Babalola, O. O. 2017. A New Strategy for Heavy Metal Polluted Environments: A Review of Microbial Biosorbents. International journal of environmental research and public health, 14(1): 94. doi:10.3390/ijerph14010094.

4. Jan, A. T., Azam, M., Siddiqui, K., Ali, A., Choi, I. and Haq, Q. M. 2015. Heavy Metals and Human Health: Mechanistic Insight into Toxicity and Counter Defense System of Antioxidants. International journal of molecular sciences, 16(12): 29592-29630. doi:10.3390/ijms161226183.

5. Jaishankar, M., Tseten, T., Anbalagan, N., Mathew, B. B. and Beeregowda, K. N. 2014. Toxicity, mechanism and health effects of some heavy metals. Interdisciplinary toxicology, 7(2): 60-72. doi:10.2478/intox-2014-0009.

6. Marouf, B. H 2018. Association between serum heavy metals level and cancer incidence in darbandikhan and Kalar Area, Kurdistan Region, Iraq, Nigerian Journal of Clinical Practice, 21(6): 766 -771.

7. Hesami, F., Bina, B., Ebrahimi, A. and Amin, M. M. 2013. Arsenic removal by coagulation using ferric chloride and chitosan from water. International Journal of Environmental Health Engineering, 2(9): $11-17$.

8. Mahmood, M., Barbooti, M., Balasim, A., Altameemi, A., Najah, M and Al-Shuwaiki, N. 2011. Removal of Heavy Metals Using Chemicals Precipitation. Engineering and Technology Journal, 29(3). 
9. Thien-Khanh, T., Hoang-Jyh, L., Kuo-Feng, C., \& Chiu-Yue, L. (2015). Electrochemical Treatment for Wastewater Contained Heavy Metal the Removing of the COD and Heavy Metal Ions, International Journal of Engineering Research and Science, 1(9): 96.

10.Pan, F. Z. and Liang, A. 2019. Removal of Heavy Metal from Wastewater Using Ion Exchange Membranes,Applications of Ion Exchange Materials in the Environment, 25 - 46. DOI: 10.1007/978-3-030-10430-6_2.

11. Khulbe, K. and Matsuura, T. 2018. Removal of heavy metals and pollutants by membrane adsorption techniques. Applied Water Science. 8. 10.1007/s13201-018-0661-6.

12. Yun-Ren, Q. and Lian-Jun, M. 2013. Removal of heavy metal ions from aqueous solution by ultrafiltration assisted with copolymer of maleic acid and acrylic acid, Desalination, 329: 78 - 85.

13.Khai, M. N., Bien, Q. N., Hai, T. N. and Ha, T.H.N. 2019. Adsorption of Arsenic and Heavy Metals from Solutions by Unmodified Iron-Ore Sludge, Applied sciences, 9(619): doi:10.3390/app9040619.

14. Muhammad, H. A. And Abdullah, A. B. 2016. Adsorption of heavy metals using activated carbon produced from municipal organic solid waste, Desalination and Water Treatment, 57(51): 2451924531, DOI: 10.1080/19443994.2016.1144536.

15.El-Maghrabi, H. and Mikhail, S. 2014. Removal of Heavy Metals via Adsorption using Natural Clay Material, Journal of Environment and Earth Science, ISSN 2224-3216 (Paper) ISSN 22250948 (Online), 4, 19.

16. Halimoon, N. and Goh, S. Y. R. 2010. Removal of Heavy Metals from Textile Wastewater using Zeolite. Environment Asia., 3: 124 - 130. 10.14456/ea.2010.51.

17.Gupta, V. and Ali, I. 2004. Removal of Lead and Chromium from Wastewater Using Bagasse Fly Ash-A Sugar Industry Waste. Journal of colloid and interface science, 271: 321-8. 10.1016/j.jcis.2003.11.007.

18.Ezzat, M. S., Salwa A. A. and Aliaa, A. F. 2011. Reactivity of sugar cane bagasse as a natural solid phase extractor for selective removal of Fe(III) and heavy-metal ions from natural water samples, Arabian Journal of Chemistry, 4(1): 63 - 70.

19.Gupta, P. and Diwan, B. 2016. Bacterial Exopolysaccharide mediated heavy metal removal: A Review on biosynthesis, mechanism and remediation strategies. Biotechnology reports (Amsterdam, Netherlands), 13: 58-71. doi:10.1016/j.btre.2016.12.006.

20.Bellich, B., D'Agostino, I., Semeraro, S., Gamini, A. and Cesàro, A. 2016. "The Good, the Bad and the Ugly" of Chitosans. Marine drugs, 14(5): 99. Doi:10.3390/md14050099.

21. American Public Health Association (APHA) 2012. American Water Works Association -Awwa; Water Pollution Control Federation -Wpcf. Standard methods for the examination of water and waste water.22th ed. Washington DC.

22.Mesdaghinia, A. R., Mosaferi, M., Yunesian, M., Naseri, S. and Mahvi, A. H. 2005. Measurement of Arsenic Concentration in Drinking water of a polluted area using a field and SDDC methods accompanied by assessment of precision and accuracy of each method. Hakim, 8: 43 - 51.

23.Steinmaus, C. M., George, C. M., Kalman, D. A. and Smith, A. H. 2006. Evaluation of two new arsenic field test kits capable of detecting arsenic water concentrations close to $10 \mu \mathrm{g} / \mathrm{L}$. Environ Science Technology, 40: $3362-6$.

24.Nouri, M. Khodaiyan, F., Razavi, S. H. and Mousavi, M. 2015. Improvement of Chitosan Production from Persian Gulf Shrimp Waste by Response Surface Technology. Food Hydrocolloids, 3: 1-9.

25.Szymanska, E. and Winnicka, K. 2015. Stability of Chitosan -A Challenge for Pharmaceutical and Biomedical Application. Marine Drugs, 13: 1819-1864.

26.Viljoen, J. M., Steekamp, J. H., Marais, A. F. And Kotze, A. F. 2014. Effect of moisture content, temperature and exposure time on the physical stability of chitosan powder and tablets. Drug Development Industrial Pharmaceuticals, 40: 730-742.

27.Puvvada, Y. S., Vankayalapati, S. And Sukhavasi, S. 2012. Extraction of Chitin from Chitosan Exoskeleton of Shrimp for Application in the Pharmaceutical Industry. International Current Pharmaceutical Journal, 1(9): 258-263.

28. Ghannam, H. E., Talab, A. S., Dolganova, N. V., Hussein, Ahmed, M. S. and Abdelmaguid, N. M. 2016. Characterization of Chitosan Extracted from Different Crustacean Shell Wastes. Journal of Applied Sciences, 16: 454-461. 
29.Isa M T, Ameh A O, Tijjani M and Adama K K. 2012. Extraction and characterization of chitin and chitosan from Nigerian shrimps. International Journal of Biology and Chemistry Science. 6: 446.

30.Abdulkarim, A., Isa, M. T., Abdulsalam, S., Muhammad, A. J. and Ameh, A. O. 2013. Extraction and Characterization of Chitin and Chitosan from Mussel Shell. Civil and Environmental Research, 3(2): $108-114$.

31.National Standardization Agency of Indonesia. 2013. Letter Number 298/KEP/BSN/12/2013 SNI 7949.

32.Zhang, X., Geng, X., Jiang, H., Li, J. and Huang, J. 2012. Synthesis and characteristics of chitin and chitosan with the (2-hydroxy- 3-trimethylammonium) propyl functionality, and evaluation of their antioxidant activity in vitro," Carbohydrate Polymers, 89: 486 -491.

33.Mythili, V. and Aysha, O.S. 2017. Synthesis and Characterization of Chitosan from Crab Shells Vs Bacteriological Biomass. World Journal of Pharmacy and Pharmaceutical Sciences, 6(5): 1563 1576.

34.MonarulIslama Shah., Md. Masumb., M. MahbuburRahma-na., Md. Ashraful Islam Mollab 2011. Preparation of Chitosan from Shrimp Shell and Investigation of its Properties. International Journal of Basic \& Applied Sciences, 11(1): 116 - 130.

35.He, G., Chen, X., Yin, Y., Zheng, H., Xiong, X. and Du, Y. 2011. Synthesis, characterization and antibacterial activity of salicyloyl chitosan. Carbohydr. Polym. 83: 1274.

36. Anand, M., Kalaivani, R., Maruthupandy, M., Kumaraguru, A.K.K. and Suresh. S. 2014. Extraction and characterization of chitosan from marine crab and squilla collected from the Gulf of Mannar Region, South India, Journal of Chitin and Chitosan Sciences, 2(2014): 280 - 287.

37.Islam, Md \& Md. Masum, Shah \& Rahman, Mohammad and Ashraful Islam, Md and A. Shaikh, A \& Roy, S.K.. 2011. Preparation of Chitosan from Shrimp Shell and Investigation of Its Properties. International Journal of Basic \& Applied Sciences IJBAS-IJENS. 11: 77-80.

38.Dina, S., Purnama, D., Sri, A., Chairil, A. and Umar, S. 2018. Preparation and Characterization of Chitosan from Indonesian Tambak Lorok Shrimp Shell Waste and Crab Shell Waste. Pakistan Journal of Nutrition, 17: 446 - 453.

39.Rotta, J., Minatti, E. and Barreto, P. L. M. 2011. Determination of structural and mechanical properties, diffractometry, and thermal analysis of chitosan and hydroxypropylmethylcellulose (HPMC) films plasticized with sorbitol," Ciência e Tecnologia de Alimentos, 31(2): 450 - 455.

40.Yen M.-T. and Mau J.-L. 2007. Physico-chemical characterization of fungal chitosan from shiitake stipes, LWT-Food Sci. Technology, 40: 472 - 479.

41.Prashanth K. V. H., Kittur F. S. And Tharanathan R. N. 2002. Solid state structure of chitosan prepared under different $N$-deacetylating conditions, Carbohydrate Polymers, 50: 27-33.

42. Younes, I. and Rinaudo, M. 2015. Chitin and chitosan preparation from marine sources. Structure, properties and applications. Marine drugs, 13(3): 1133-1174. doi:10.3390/md13031133.

43. Krishnaveni, B. and Ragunathan, R. 2015. Extraction and characterization of chitin and Chitosan from Aspergillus terreus sps, synthesis of their bionanocomposites and study of their productive application. Journal of Chemistry and Pharmaceutical Research, 7(2): 115 - 132.

44.Swapp, S. 2012. Scanning Electron Microscopy (SEM). Available: http:// serc.carleton.edu / research_education/geochemsheets/techniques/SEM.html.

45. Barbara, B., Ilenia, D., Sabrina, S., Amelia, G. And Attilio, C. 2016. Review: The Good, the Bad and the Ugly" of Chitosans, Marine Drugs, 14(5): 99.

46.Rizzi, M., D`Aloia, M. and Castagnolo, B. 2010. Semiconductor Detectors and Principles of Radiation-matter Interaction. Journal of Applied Sciences, 10: 3141 - 3155.

47. Chattopadhyay, D. P. and Inamdar, M. S. 2012. Studies on Synthesis, Characterization and Viscosity Behaviour of Nano Chitosan, Research Journal of Engineering Sciences, 1(4): 9 - 15.

48.Jonassen, H., Kjøniksen, A. L. and Hiorth, M. 2012. Stability of chitosan nanoparticles crosslinkedwith tripolyphosphate. Biomacromolecules, 13: 3747 - 3756.

49. Agarwal, M., Agarwal, M. K., Shrivastav, N., Pandey, S., Das, R. and Gaur, P. 2018. Preparation of Chitosan Nanoparticles and their In-vitro Characterization. International Journal of Life. Sciences and Scientific Research, 4(2): 1713 - 1720.

50.Thien, D., An, N. And Hoa, N. 2015. Preparation of Fully Deacetylated Chitosan for Adsorption of Hg (II) Ion from Aqueous Solution. Chemical Sciences Journal. 6. 10.4172/2150-3494.100095. 
51.Bwatanglang, I.B., Mohammad, F., Yusof, N.A., Abdullah, J., Hussein, M. Z., Alitheen, N. B. and Abu, N. 2016. Folic acid targeted Mn: $\mathrm{ZnS}$ quantum dots for theranostic applications of cancer cell imaging and therapy, International of Journal of Nanomedicine, 11: 413 - 428.

52.Igberase, E., Osifo, P. and Ofomaja, A. 2017. The Adsorption of $\mathrm{Pb}, \mathrm{Zn}, \mathrm{Cu}, \mathrm{Ni}$, and $\mathrm{Cd}$ by Modified Ligand in a Single Component Aqueous Solution: Equilibrium, Kinetic, Thermodynamic and Desorption Studies. International Journal of Analytical Chemistry, 15. https:// doi.org /10.1155/2017/6150209.

53. Aderonke A. O., Abimbola, B. A., Ifeanyi, E. O., Omotayo, S. A.,Oluwagbemiga S. A. and Oladotun, W. M Adsorption of heavy metal ions onto chitosan grafted cocoa husk char. African Journal of Pure and Applied Chemistry, 8(10): 147 - 161.

54.Dada, A.O, Olalekan, A. P, Olatunya, A.M. and DADA, O. 2012. Langmuir, Freundlich, Temkin and Dubinin-Radushkevich Isotherms Studies of Equilibrium Sorption of $\mathrm{Zn}^{2+}$ unto Phosphoric Acid Modified Rice Husk, IOSR Journal of Applied Chemistry, 3(1): 38-45.

55.Igberase, E., Osifo, P. and Ofomaja, A. 2017. The Adsorption of $\mathrm{Pb}, \mathrm{Zn}, \mathrm{Cu}, \mathrm{Ni}$, and $\mathrm{Cd}$ by Modified Ligand in a Single Component Aqueous Solution: Equilibrium, Kinetic, Thermodynamic, and Desorption Studies. International journal of analytical chemistry, 2017, 6150209. doi:10.1155/2017/6150209.

56. Rathod, M., Mody, K. and Basha, S. 2014. Efficient removal of phosphate from aqueous solutions by red seaweed, Kappaphycus alverezii. Journal of Cleaner Production, 84(1): 484 - 493.

57.Tarisai, V., Kriveshini, P. and Xavier, Y. M. 2017. Kinetic and Thermodynamic Studies for the Removal of Cr (VI) from Aqueous Solutions using Phosphonic Acid Functionalized Multiwalled Carbon Nanotubes. Research Journal of Environmental Sciences, 11: 116 - 129.

58. Kowanga, K. D., Gatebe, E., Mauti, G. O. and Mauti, E. M. 2016. Kinetic, sorption isotherms, pseudo-first-order model and pseudo-second-order model studies of $\mathrm{Cu}(\mathrm{II})$ and $\mathrm{Pb}(\mathrm{II})$ using defatted Moringa oleiferaseed powder. The Journal of Phytopharmacology; 5(2): 71 - 78.

59.Elsay, M., Menberu, Y. and Tesfaye, R. S. 2015. Kinetic and Thermodynamic Studies of the Adsorption of Cr (VI) onto Some Selected Local Adsorbents, South African Journal of Chemistry, 68: $45-52$.

60.Masood, A. K., Amanual, A., Ramesh, D. and Abiyu, K. B. 2015. Removal of Lead ion from aqueous solution by Bamboo activated Carbon, International Journal of Water Research, 5(2): 33 $-46$.

61.Feng, X., Fugang, W., Shuai, C., Shengui, J. and Weihong, X. 2017. Adsorption Equilibrium, Kinetics, and Thermodynamic Studies of Cefpirome Sulphate by Using Macroporous Resin, Journal of Chemical \& Engineering Data, 62(12): 4266 - 4272. DOI: 10.1021/acs.jced.7b00629.

62.Himani, M. and Krishna, G. B. 2017. Kinetic and mechanistic studies on adsorption of $\mathrm{Cu}$ (II) in aqueous medium onto montmorillonite K10 and its modified derivative. New Journal of Chemistry, 41: $13533-13552$.

63.Lu, X., Tang, B., Zhang, Q., Liu, L., Fan, R. and Zhang, Z. 2018. The Presence of Cu Facilitates Adsorption of Tetracycline (TC) onto Water Hyacinth Roots. International journal of environmental research and public health, 15(9): 1982. Doi: 10.3390/ijerph15091982.

64. Aseel, M. A., Abbas, N.A. and Ayad, F.A. 2017. Kinetics and equilibrium study for the adsorption of textile dyes on coconut shell activated carbon, Arabian Journal of Chemistry, 10(2): 3381 3393. 